\title{
Effect of Biocompost and Arbuscular Mycorrhizal Fungi on Chemical Properties of Inceptisols and Mychorrizal Root Infection in Purple Corn Plant
}

\author{
Yusra*, Rosnina and Dewi Sartika Aryani \\ Department of Agroecotechnology, Faculty of Agriculture, University of Malikussaleh \\ Jl. Cot Tengku Nie Reuleut, Muara Batu, Aceh Utara 24355, Indonesia \\ *email: yusra@unimal.ac.id
}

Received March 16, 2021; Revised April 22, 2021; Accepted 27 May 2021

\begin{abstract}
Inceptisols soil is categorized as underdeveloped soil which dominates agricultural lands in Indonesia. This soil exhibits minimal horizon, low pH (4.5-6.5), organic matter, and macro and micronutrients. However, the use of proper technology is believed can overcome these scarcities. The purpose of this study was to evaluate the application of bio compost and arbuscular mycorrhizal fungi (AMF) on the chemical properties of Inceptisols and root mycorrhizal infection on the purple corn plant. This research was conducted at Experimental Garden, Faculty of Agriculture, the University of Malikussaleh in Reuleut Village, Muara Batu District, Aceh Utara. The research was conducted in a Randomized Block Design (RBD) with a 4x3 factorial treatment. The first factor was bio compost dose with four levels which were B0 $\left(0 \mathrm{Mg} \mathrm{ha}^{-1}, 0 \mathrm{~g} \mathrm{plot}^{-1}\right)$, B1 $\left(5 \mathrm{Mg} \mathrm{ha}^{-1}, 1500 \mathrm{~g} \mathrm{plot}^{-1}\right)$, B2 $\left(10 \mathrm{Mg} \mathrm{ha}^{-1}, 3000 \mathrm{~g} \mathrm{plot}^{-1}\right)$, and B3 (15 Mg ha-1, $\left.4500 \mathrm{~g} \mathrm{plot}^{-1}\right)$. The second factor was AMF (mycorrhiza Gigaspora sp.) with three levels which were M0 (0 Mg ha-1 $\left.0 \mathrm{~g} \mathrm{plot}^{-1}, 0 \mathrm{~g} \mathrm{plant}^{-1}\right), \mathrm{M} 1\left(0.25 \mathrm{Mg} \mathrm{ha}^{-1}, 75 \mathrm{~g} \mathrm{plot}^{-1}, 5 \mathrm{~g} \mathrm{plant}^{-1}\right)$ dan M2 $\left(0.5 \mathrm{Mg} \mathrm{ha}^{-1}, 150\right.$ $\left.\mathrm{g} \mathrm{plot}^{-1}, 10 \mathrm{~g} \mathrm{plant}^{-1}\right)$. The bio compost and AMF increased soil $\mathrm{pH}$ from 5.0 to 5.5; the bio compost application improved the organic $\mathrm{C}$ (from $1.58 \%$ to $2.98 \%$ ); the application of AMF improved the root mycorrhizal infection by $90 \%$. The application of $5 \mathrm{Mg} \mathrm{ha}^{-1}$ bio compost and $0.5 \mathrm{Mg} \mathrm{ha}^{-1}$ mycorrhizae was the best dose to improve the chemical properties of Inceptisols and mycorrhizal infection in purple corn plant root.
\end{abstract}

Keywords: Biocompost, inceptisols, mycorrhizal fungi, purple corn

\section{INTRODUCTION}

Marginal or suboptimal soils such as Inceptisols possess low $\mathrm{pH}$ and nutrient contents. The $\mathrm{N}$ uptake is reduced due to lower $\mathrm{pH}$ and drought. Drought stress in plants will physiologically affect photosynthesis activity, contributing to lower photosynthate production, leading to yield deterioration. Acidic $\mathrm{pH}$, moderate organic $\mathrm{C}$, and low nutrients $(\mathrm{N}, \mathrm{P}$, and $\mathrm{K})$ are thought to be the cause of the yields loss (Mulyani et al. 2017; Aliyu et al. 2020; Patra et al. 2020) and also limiting factors related to chemical and biological properties of the soil. Therefore, the use of Arbuscular Mycorrhizal Fungi (AMF) is considered one of the best ways to improve the fertility of inceptisol soils (Nurbaity et al. 2019).

J Trop Soils, Vol. 26, No. 2, 2021: 87-93

ISSN 0852-257X; E-ISSN 2086-6682
Inceptisol soils are usually considered arable with appropriate control of erosion or drainage and can be used for agricultural fields. They can be improved by applying soil reinforcement, adding some organic materials, enhancing nutrients, and stimulating the beneficial living microorganisms in the soil (Funderburg 2020). The application of biocompost is believed to enhance the nutrients in the soil and activate the microorganisms in the soils, contributing to the increase of marginal soil productivity. The presence of beneficial microorganisms, such as bacteria and fungi, in the soils helps to reinstate the degraded soils/lands (Kumar et al. 2017; Sinha et al. 2017; Cremeneac and Boclaci (2018); Barkha et al. 2020; Bertham et al. 2020).

The application of mycorrhizae also contributes to soil improvement. Its hyphae generate the physical properties of soil by loosening the soil. Previous research has found that this living organism 
helps plants expand the plant's room and absorption area, helping them reach farther into the soil to absorb the water and nutrients under drought stress (Zhang et al. 2018; Püschel et al. 2020; Hou et al. 2021). Wright and Upadhyaya (1998) also stated that mycorrhizal hyphae produce glomalin content, and organic acids composing micro aggregates become macro aggregates absorbed by plants.

Maize (Zea mays L.) is a promising food crop that can be grown in Inceptisol soil. However, maize productivity is influenced by a complex interaction between its plant characteristics and environment, such as soil. The low yield of maize planted in Inceptisol soil is contributed by lower soil fertility, where it possesses lower organic materials, $\mathrm{pH}$, lower nutrients such as $\mathrm{N}, \mathrm{P}, \mathrm{K}, \mathrm{Mg}$, and $\mathrm{Ca}$, and higher Fe and Al (Soepardi 1983). Therefore, the growth and yield of maize depend on the way we treat and manage the soil. Several maize varieties have been developed in Indonesia. One of the essential maize varieties is purple maize/corn (Zea mays var. ceratina Kulesh). Mahendradatta \& Tawali (2008) informed that purple corn could be developed due to its high amylopectin, sweet taste, fluffy appearance, and exciting aroma.

Therefore, the research aimed to evaluate the practical application of biocompost and mycorrhizal fungi on the chemical properties of Inceptisols and the root mycorrhizal infection of purple corn plants in suboptimal soil.

\section{MATERIALS AND METHODS}

\section{Study Site}

The research was conducted at Experimental Garden, Faculty of Agriculture, the University of Malikussaleh in Reuleut Village, Muara Batu District, Aceh Utara Regency.

\section{Experimental Design}

A field experiment was conducted. The study employed a Randomized Block Design (RBD) with two factors. The first factor was biocompost (B) with 4 level dose: B0 $\left(0 \mathrm{Mg} \mathrm{ha}^{-1}, 0 \mathrm{~g} \mathrm{plot}^{-1}\right), \mathrm{B} 1$ (5 $\left.\mathrm{Mg} \mathrm{ha}^{-1}, 1500 \mathrm{~g} \mathrm{plot}^{-1}\right)$, B2 (10 $\mathrm{Mg} \mathrm{ha}^{-1}, 3000 \mathrm{~g}$ plot $^{-1}$ ) and B3 (15 Mg ha-1, $\left.4500 \mathrm{~g} \mathrm{plot}^{-1}\right)$. The second factor was mycorrhizal fungi Gigaspora sp. (M) with 3 three-level dose: M0 (0 $\mathrm{Mg} \mathrm{ha}^{-1}, 0 \mathrm{~g}$ plot $^{-1}, 0$ g plant $\left.^{-1}\right)$, M1 (0.25 Mg ha-1 75 g plot $^{-1}, 5$ $\left.\mathrm{g}_{\text {plant }}{ }^{-1}\right)$ and $\mathrm{M} 2\left(0.5 \mathrm{Mg} \mathrm{ha}^{-1}, 150 \mathrm{~g} \mathrm{plot}^{-1}, 10 \mathrm{~g}\right.$ plant $\left.^{-1}\right)$. There were 12 experimental units with three replications, which resulted in 36 experimental units in total.

At the beginning of the research, sample soils were taken for laboratory analysis to check the initial soil chemical properties. The field experiment was started by tilling the soil, incubated for one week, and then the soil was treated with $5 \mathrm{Mg}$ manure $\mathrm{ha}^{-1}$ as a base treatment. Then, the maize was planted, and the biocompost and mycorrhizal fungi were applied. At 45 days after planting, the soils were analyzed for $\mathrm{pH}\left(\mathrm{H}_{2} \mathrm{O}\right), \mathrm{pH}(\mathrm{KCl})$, Organic C (\%), Total P (\%), cations exchange capacity (me $100 \mathrm{~g}^{-1}$ ), exchangeable aluminum (me $100 \mathrm{~g}^{-1}$ ), exchangeable hydrogen $\left(\mathrm{me} 100 \mathrm{~g}^{-1}\right.$ ) and root mycorrhizal infection (\%).

\section{Soil Chemical Analysis}

The initial soil properties of Inceptisols are described in Table 1; the soil chemical properties are low. The Inceptisols soil in Reuleut Village, Aceh Utara, has acidic $\mathrm{pH}$, low organic $\mathrm{C}$, total $\mathrm{P}$, and cation exchange capacity (CEC). These results indicated that this soil needed organic materials to increase its organic $\mathrm{C}$ and $\mathrm{CEC}$ to support the maize growth.

Table 1. Initial soil chemical properties of Inceptisols in Reuleut Village.

\begin{tabular}{|c|c|c|c|}
\hline No. & Soil properties & Value & Category \\
\hline 1 & $\mathrm{pH}\left(\mathrm{H}_{2} \mathrm{O}\right)$ & 5.0 & Acidic \\
\hline 2 & $\mathrm{pH}(\mathrm{KCl})$ & 4.3 & Strongly acidic \\
\hline 3 & Organic C $(\%)$ & 1.58 & Low \\
\hline 4 & Total P (mg $\left.100 g^{-1}\right)$ & 12.17 & Low \\
\hline 5 & Cation exchange capacity (me $100 \mathrm{~g}^{-1}$ ) & 12.78 & Low \\
\hline 6 & Exchangeable aluminum (me $\left.100 \mathrm{~g}^{-1}\right)$ & 0.73 & - \\
\hline 7 & Exchangeable hydrogen (me $\left.100 \mathrm{~g}^{-1}\right)$ & 1.46 & - \\
\hline
\end{tabular}

Source: Balai Penelitian Tanah (2009) 


\section{Statistical Analysis}

The data collected were analyzed using the $\mathrm{F}$ test (Gomez and Gomez 1995). Then, significant differences were performed using Duncan Multiple Range Test (DMRT) at a 5\% probability level.

\section{RESULTS AND DISCUSSION}

The result of ANOVA about the effect of biocompost and mycorrhizal fungi on soil chemical properties of Inceptisol is presented in Table 2. The results showed that the application of biocompost significantly affected soil $\mathrm{pH}\left(\mathrm{H}_{2} \mathrm{O}\right)$ and organic $\mathrm{C}$. While, the application of mycorrhizal fungi significantly affected the mycorrhizal root infections. Furthermore, there was an interaction between the application of biocompost and mycorrhizal fungi on the increase of soil $\mathrm{pH}\left(\mathrm{H}_{2} \mathrm{O}\right)$; however, no interaction on other variables.

\section{Effect of Biocompost and Mycorrhizal Fungi on Soil Chemical Properties of Inceptisols}

The ANOVA results showed that the application of biocompost and mycorrhizal fungi had no significant effect on variables observed, except on soil $\mathrm{pH}\left(\mathrm{H}_{2} \mathrm{O}\right)$ (Table 2). Effect the application of biocompost and mycorrhizal fungi on $\mathrm{pH}\left(\mathrm{H}_{2} \mathrm{O}\right)$, $\mathrm{pH}(\mathrm{KCl})$, organic $\mathrm{C}$, and total $\mathrm{P}$ of Inceptisol soil in Reuleut Village is presented in Table 3. There was a slight increase in the soil $\mathrm{pH}$ at 45 days compared to the initial $\mathrm{pH}$ value. The application of biocompost enormously increased the organic $\mathrm{C}$ (low to moderate), while total $\mathrm{P}$ slightly increased, although it did not change its category.

Table 2. The effect of application of biocompost and mycorrhizal fungi on soil chemical properties of inceptisols in Reuleut Village and mycorrhizal infection.

\begin{tabular}{|c|c|c|c|c|}
\hline No & Soil properties & Bio compost & Mycorrhizal fungi & Interaction \\
\hline 1 & $\mathrm{pH}\left(\mathrm{H}_{2} \mathrm{O}\right)$ & $*$ & ns & $*$ \\
\hline 2 & $\mathrm{pH}(\mathrm{KCl})$ & ns & ns & ns \\
\hline 3 & Organic $\mathrm{C}$ & ** & ns & ns \\
\hline 4 & Total P & ns & ns & ns \\
\hline 5 & Cation exchange capacity (me $\left.100 \mathrm{~g}^{-1}\right)$ & $\mathrm{ns}$ & ns & ns \\
\hline 6 & Exchangeable aluminum $\left(\right.$ me $\left.100 \mathrm{~g}^{-1}\right)$ & $\mathrm{ns}$ & ns & $\mathrm{ns}$ \\
\hline 7 & Exchangeable hydrogen $\left(\mathrm{me} 100 \mathrm{~g}^{-1}\right)$ & ns & ns & ns \\
\hline 8 & Mycorrhizal infection (\%) & $\mathrm{ns}$ & $* *$ & $\mathrm{~ns}$ \\
\hline
\end{tabular}

*significant, **highly significant, $\mathrm{ns}=$ non-significant

Table 3. The effect of biocompost and mycorrhizal fungi on $\mathrm{pH}\left(\mathrm{H}_{2} \mathrm{O}\right), \mathrm{pH}$ $(\mathrm{KCl}), \mathrm{C}-$ Organic, and P-total of inceptisol soils in Reuleut Village.

\begin{tabular}{lcccc}
\hline Treatment & $\begin{array}{c}\mathrm{pH} \\
\left(\mathrm{H}_{2} \mathrm{O}\right)\end{array}$ & $\begin{array}{c}\mathrm{pH} \\
(\mathrm{KCl})\end{array}$ & $\begin{array}{c}\text { Organic } \\
\mathrm{C}(\%)\end{array}$ & $\begin{array}{c}\text { Total P } \\
\left(\mathrm{mg} \mathrm{100g}^{-1}\right)\end{array}$ \\
\hline $\mathrm{B}_{0} \mathrm{M}_{0}$ & $4.8 \mathrm{c}$ & 3.8 & 2.96 & 12.56 \\
$\mathrm{~B}_{0} \mathrm{M}_{1}$ & $4.9 \mathrm{c}$ & 4.0 & 2.30 & 13.70 \\
$\mathrm{~B}_{0} \mathrm{M}_{2}$ & $5.1 \mathrm{bc}$ & 3.8 & 2.99 & 18.87 \\
$\mathrm{~B}_{1} \mathrm{M}_{0}$ & $5.1 \mathrm{bc}$ & 3.9 & 2.60 & 18.87 \\
$\mathrm{~B}_{1} \mathrm{M}_{1}$ & $5.3 \mathrm{ab}$ & 3.9 & 2.41 & 15.91 \\
$\mathrm{~B}_{1} \mathrm{M}_{2}$ & $5.5 \mathrm{a}$ & 3.3 & 2.95 & 19.39 \\
$\mathrm{~B}_{2} \mathrm{M}_{0}$ & $5.2 \mathrm{abc}$ & 3.8 & 2.70 & 14.78 \\
$\mathrm{~B}_{2} \mathrm{M}_{1}$ & $5.0 \mathrm{bc}$ & 4.0 & 2.81 & 13.65 \\
$\mathrm{~B}_{2} \mathrm{M}_{2}$ & $5.2 \mathrm{abc}$ & 4.1 & 2.61 & 17.39 \\
$\mathrm{~B}_{3} \mathrm{M}_{0}$ & $5.2 \mathrm{abc}$ & 4.2 & 3.15 & 14.78 \\
$\mathrm{~B}_{3} \mathrm{M}_{1}$ & $5.3 \mathrm{ab}$ & 4.1 & 3.39 & 16.65 \\
$\mathrm{~B}_{3} \mathrm{M}_{2}$ & $5.2 \mathrm{abc}$ & 4.1 & 3.46 & 18.87 \\
\hline
\end{tabular}

Note: $\mathrm{B}=$ Biocompost; $\mathrm{M}=$ Mycorrhizal fungi; B0 (0 Mg ha-1); B1 (5 Mg ha-1); B2 (10 Mg ha' $)$; B3 (15 Mg ha-1); M0 (0 Mg ha $\left.{ }^{-1}\right)$; M1 (0.25 Mg ha $\left.{ }^{-1}\right)$; M2 (0.5 Mg ha $\left.{ }^{-1}\right)$ 
The application of biocompost and mycorrhizal fungi significantly increased the soil $\mathrm{pH}\left(\mathrm{H}_{2} \mathrm{O}\right)$. The best $\mathrm{pH}$ value (5.5) was revealed by applying biocompost $5 \mathrm{Mg} \mathrm{ha}^{-1}$ and mycorrhizal fungi $0.5 \mathrm{Mg}$ $\mathrm{ha}^{-1}$. The slow improvement of soil $\mathrm{pH}$ is linked to the characteristic of biocompost as a buffer to the soil. Organic matter is also a factor affecting the soil $\mathrm{pH}$. With an increase in organic matter, the soil recovers its natural buffer capacity, increasing $\mathrm{pH}$ in acid soils. At low $\mathrm{pH}$, aluminum becomes soluble, and organic matter forms together with aluminum, which is the primary soil $\mathrm{pH}$ buffering capacity. At high $\mathrm{pH}$, the organic matter contributes to soil acidification by binding with non-acidic cations such as $\mathrm{Ca}^{2+}$ and $\mathrm{Mg}^{2+}$, which they can be easily lost to leaching (Husson 2013). Stevenson (1994) confirmed that humus soils contain some functional groups (carboxyl, phenolic $\mathrm{OH}$ ), which play a pivotal role in regulating cation exchange in soil, contributing to constant $\mathrm{H}^{+}$and unchanged acidic soil.

Karnilawati et al. (2013) stated that the mycorrhizal fungi applied in the soil could be associated with plant roots, improving soil structure and maintain better soil $\mathrm{pH}$. The increase of soil $\mathrm{pH}$ due to mycorrhizal fungi application has proven to produce several compounds which can bind soil metals such as Al, Fe, dan Mn. The improvement of organic $\mathrm{C}$ due to biocompost application resulted from the release of organic $\mathrm{C}$ of biocompost itself. The result is in line with Arifiati et al. (2017) that an increase of organic $\mathrm{C}$ is caused by the release of organic $\mathrm{C}$ from the application of biocompost. The difference in organic matter value is attributed to biocompost application and its decomposition by microorganisms in the soil. Sutanto (2002) explained that organic matter produced by organic fertilizer has been using by living microorganisms in the soil as the source of energy and reproduction, and their population determines the amount of organic matter in the soil.

Total $\mathrm{P}$ in the soil has increased even though it was still considered low and insignificant, from 12.17 mg $100 \mathrm{~g}^{-1}$ to $19.39 \mathrm{mg} 100 \mathrm{~g}^{-1}$ (B1M2 treatment). However, the addition of mycorrhizae was able to fix the roots of maize plants. In addition, a mycorrhizal fungus used in this study, Gigaspora sp., was able to exhibit a good effect on plant growth and root infection. The result follows the research of Chalimah et al. (2007), who stated that the application of mycorrhizal fungi Gigaspora sp. has increased plant biomass, the number of spores, and root infection. Research by Fitter and Hay (1991) and Lakitan (2000) stated that the fungus Gigaspora sp. hyphae penetrate the cells of the host plant's cortex from one cell to another so that they are strong enough to transfer the nutrients from the soil to plants and to free the carbon and phosphorus elements so that plants can utilize them to increase plant biomass, number of spores and also the degree of root infection. According to Bakhtiar (2002), mycorrhizal colonization is influenced by the type of spore. The ability of spores to infect, its effectiveness and compatibility with the host, and environmental factors, influence the root colonization.

Table 4. Effect of biocompost and mycorrhizal fungi on cation exchange capacity, exchangeable aluminum, exchangeable hydrogen of inceptisols, and mycorrhizal infection

\begin{tabular}{|c|c|c|c|c|}
\hline Treatment & $\begin{array}{c}\text { Cation exchange } \\
\text { capacity } \\
\left(\mathrm{me} 100 \mathrm{~g}^{-1}\right) \\
\end{array}$ & $\begin{array}{c}\text { Exchangeable } \\
\text { aluminium } \\
\left(\text { me } 100 \mathrm{~g}^{-1}\right)\end{array}$ & $\begin{array}{c}\text { Exchangeable } \\
\text { hydrogen } \\
\left(\mathrm{me} 100 \mathrm{~g}^{-1}\right)\end{array}$ & $\begin{array}{c}\text { Mycorrhizal } \\
\text { colonization } \\
(\%) \\
\end{array}$ \\
\hline $\mathrm{B}_{0} \mathrm{M}_{0}$ & 14.55 & 0.96 & 0.39 & 20.00 \\
\hline $\mathrm{B}_{0} \mathrm{M}_{1}$ & 16.72 & 0.52 & 0.41 & 60.00 \\
\hline $\mathrm{B}_{0} \mathrm{M}_{2}$ & 16.54 & 0.46 & 0.46 & 73.33 \\
\hline $\mathrm{B}_{1} \mathrm{M}_{0}$ & 18.72 & 0.34 & 0.43 & 43.33 \\
\hline $\mathrm{B}_{1} \mathrm{M}_{1}$ & 20.02 & 0.34 & 0.34 & 63.33 \\
\hline $\mathrm{B}_{1} \mathrm{M}_{2}$ & 21.72 & 0.88 & 0.24 & 63.33 \\
\hline $\mathrm{B}_{2} \mathrm{M}_{0}$ & 18.11 & 0.36 & 0.36 & 16.67 \\
\hline $\mathrm{B}_{2} \mathrm{M}_{1}$ & 16.51 & 0.34 & 0.27 & 63.33 \\
\hline $\mathrm{B}_{2} \mathrm{M}_{2}$ & 15.81 & 0.68 & 0.44 & 53.33 \\
\hline $\mathrm{B}_{3} \mathrm{M}_{0}$ & 15.37 & 0.48 & 0.26 & 23.33 \\
\hline $\mathrm{B}_{3} \mathrm{M}_{1}$ & 13.48 & 0.66 & 0.66 & 56.67 \\
\hline $\mathrm{B}_{3} \mathrm{M}_{2}$ & 18.46 & 0.54 & 0.54 & 90.00 \\
\hline
\end{tabular}

Note: B = Biocompost; $\mathrm{M}=$ Mycorrhizal fungi; B0 (0 Mg ha-1); B1 (5 Mg ha-1); B2 (10 Mg ha-1); B3 (15 Mg ha-1); M0 $\left(0 \mathrm{Mg} \mathrm{ha}^{-1}\right) ; \mathrm{M} 1\left(0.25 \mathrm{Mg} \mathrm{ha}^{-1}\right) ; \mathrm{M} 2\left(0.5 \mathrm{Mg} \mathrm{ha}^{-1}\right)$. 
The results of the application of biocompost and mycorrhizal fungi on cation exchange capacity (CEC), exchangeable aluminum, exchangeable hydrogen, and mycorrhizal colonization are presented in Table 4. The cation exchange capacity demonstrated an increase, even though it was not significant. In contrast, it has shown a decrease in exchangeable aluminum and exchangeable hydrogen generally. However, the application of mycorrhizal fungi alone has improved the purple corn, indicated by a high percentage of fungal colonization on its roots.

Total $\mathrm{P}$ and CEC possessed a non-significant increase. The highest total $\mathrm{P}\left(19.39 \mathrm{mg}^{-100 \mathrm{~g}^{-1}}\right)$ was revealed by applying biocompost $5 \mathrm{Mg} \mathrm{ha}^{-1}$ and mycorrhizal fungi $0.5 \mathrm{Mg} \mathrm{ha}^{-1}$. This improvement was considered low and insignificant due to different biocompost application doses and $\mathrm{P}$ in organic matter (Arifin et al. 2000). Furthermore, this organic matter is also able to influence the soil CEC by donating anions. Besides, organic matter can increase $\mathrm{P}$ availability, especially in soil with high hydroxide Al and Fe and colloidal properties (Yusra 2010).

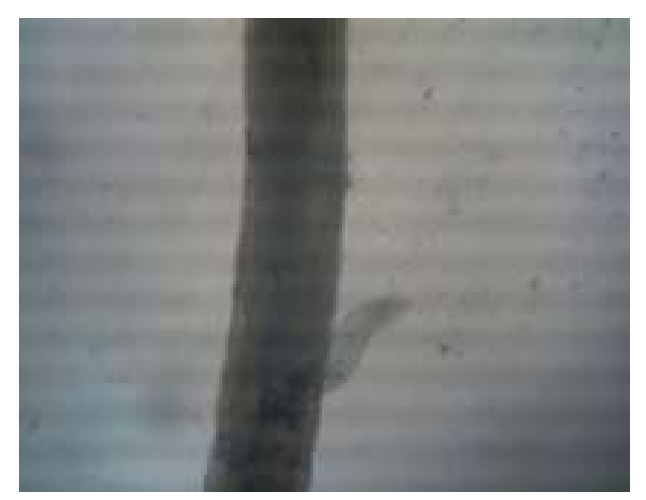

Figure 1. Untreated roots (AMF $0 \mathrm{Mg} \mathrm{ha}^{-1}$ ).

Figure 2. Root treated with AMF $0.25 \mathrm{Mg} \mathrm{ha}^{-1}$.

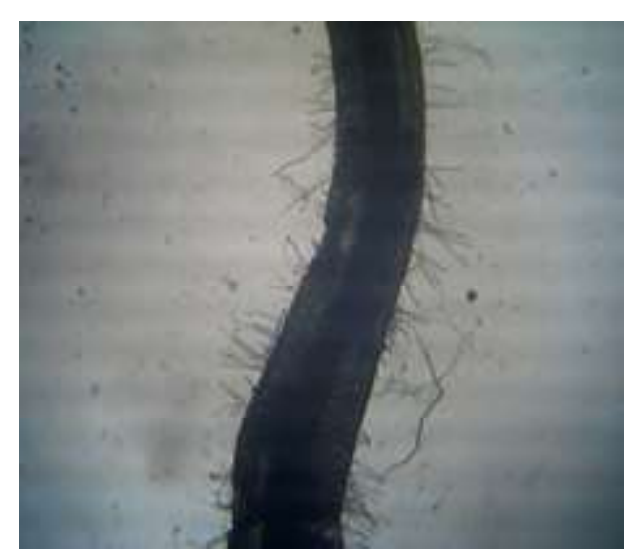

\section{Effect of Biocompost and Mycorrhizal Fungi on Mycorrhizal Root Infection of the Purple Corn Plant}

The result of the application of biocompost and mycorrhizal fungi on mycorrhizal colonization is shown in Table 4. Mycorrhizal colonization on the treated roots of the purple corn plant was found to be high $(90 \%)$ compared to control, demonstrated by the application of biocompost $15 \mathrm{Mg} \mathrm{ha}^{-1}$ and mycorhizal fungi $0.5 \mathrm{Mg} \mathrm{ha}^{-1}$ (Figures 1, 2 and 3). This finding corroborates with researches by Rajapakse and Miller (1992) and Ayu et al. (2015), where $76 \%-100 \%$ of mycorrhizal infection is considered a high percentage. Ningrum et al. (2013) also added that this high percentage caused by photosynthesis activity, where the photosynthate is distributed to the roots as a source of carbon to mycorrhizal fungi, enabling them to produce spores in a more tremendous amount. Therefore, it can be said that the symbiotic relationship between mycorrhizal fungi and purple

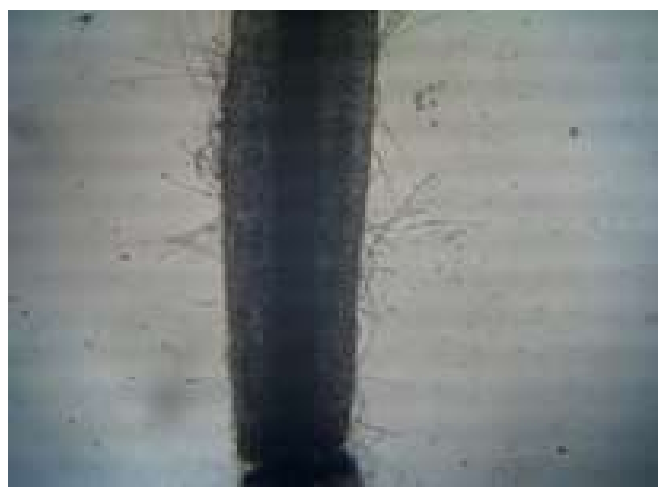

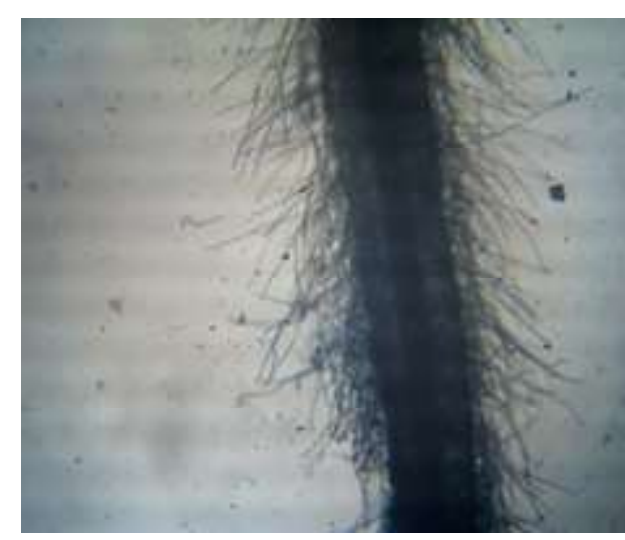

Figure 3. Root treated with AMF $0.5 \mathrm{Mg} \mathrm{ha}^{-1}$. 
corn roots is essential in producing high yields $(\mathrm{Bi}$ et al. 2018; Pinos et al. 2019).

Overall, several factors are affecting these insignificant and low results of organic $\mathrm{C}$, total $\mathrm{P}$, and CEC in the Inceptisol soil in Reuleut, Aceh Utara Regency, such as the delay soil response of treatment applied due to shallow soil, weak soil weathering, which just sufficient for mild development and they commonly found either with underlying weatheringresistant parent material, for example, opaque, quartzite and siliceous sands (Pinto et al. 2016; Muslim et al. 2020).

\section{CONCLUSIONS}

The application of biocompost and mycorrhizal fungi has increased soil $\mathrm{pH}\left(\mathrm{H}_{2} \mathrm{O}\right)$ from 5.0 to 5.5. On the other hand, the application of biocompost improved the organic C from $1.58 \%$ to $2.98 \%$. Gigaspora sp. has been found to increase the root colonization up to $90 \%$ even though the total $\mathrm{P}$ was categorized low. The application of biocompost 5 $\mathrm{Mg} \mathrm{ha} \mathrm{h}^{-1}$ and mycorrhizal fungi $0.5 \mathrm{Mg} \mathrm{ha}^{-1}$ was the best treatment to improve the chemical properties of inceptisols in Reuleut Village and enhance the roots mycorrhizal infection of the purple corn plant.

\section{ACKNOWLEDGMENTS}

We thank Universitas Malikussaleh for providing the research grant through PNBP funding with contract no. 246/PPK-2/SPK-JL/2020.

\section{REFERENCES}

Aliyu NA, R Ismail, MM Yusoff, MFM Anuar and AGK Naisa. 2020. Soil nutrient status of sudan savanna inceptisol (Nigeria) amended with jatropha (Jatropha curcas L.) foliage. Int $J$ Modern Agr 9: 113-131.

Arifiati A, Syekhfani and Y Nuraini. 2017. Uji efektivitas perbandingan bahan kompos paitan (Tithonia diversifolia), tumbuhan paku (Dryopteris filixmas), dan kotoran kambing terhadap serapan $\mathrm{N}$ tanaman jagung pada inceptisol. J Tanah dan Sumberdaya Lahan 4: 543-552. (in Indonesian).

Arifin M, S Maryam, D Ardi and ES Trinurani. 2000. Efisiensi penggunaan pupuk p dengan bahan organik pada tanah andisols. Laporan Hasil Penelitian. Lembaga Penelitian Universitas Padjadjaran bekerjasama dengan Agricultural Research Management Project-II Badan Penelitian dan Pengembangan Pertanian, Deptan. Bandung. (in Indonesian)
Ayu PS, AN Zozy and Solfiyeni. 2015. Pertumbuhan rumput kerbau (Paspalum conjugatum Berg.) yang diinokulasi beberapa dosis fungi mikoriza arbuskular (FMA) pada media yang mengandung merkuri $(\mathrm{Hg}) . \mathrm{J}$ Biologi Universitas Andalas 4: 107-112. (in Indonesian)

Bakhtiar Y. 2002. Selection of vascular mycorrhiza (VAM), host plants, and spore numbers for producing inoculum. J Biosains and Bioteknologi Indonesia 2:36-40.

Balai Penelitian Tanah. 2009. Analisis kimia tanah, tanaman, air dan pupuk. Departemen Pertanian. Bogor. (in Indonesian).

Barkha MK, N Joshi and TD Vaghela. 2020. Effect of integrated nutrient management on growth, yield, nutrient uptake, and soil nutrient status of summer green gram (Vigna radiata L.) under south Gujarat conditions. Int J Chem Stud 8: 2675-2678.

Bertham YH, AD Nusantara, A Andani, A Anandyawati and W Herman. 2020. The improvement of coastal soil fertility using soil conditioner from biocompost inoculated with phosphate-solubilizing microbes, Bradyrhizobium, and arbuscular mycorrhizal fungi increases soybean production. Int J Agr Tech 16: 575-588.

Bi Y, L Qiu, Y Zhakypbek, B Jiang, Y Cai and H Sun. 2018. The combination of plastic film mulching and AMF inoculation promotes maize growth, yield, and water use efficiency in the semiarid region of Northwest China. Agr Water Manage 201: 278-286.

Chalimah S, Muhadiono, L Aznam, S Haran and NT Mathius. 2007. Perbanyakan Gigaspora sp. dan Acaulospora dengan kultur pot di Rumah Kaca. Biodiversitas 7: 12-19. (in Indonesian).

Cremeneac L and T Boclaci. 2018. The role of efficient microorganisms in the process of obtaining the bio compost. Scientific Papers Series-Management, Economic Engineering in Agriculture and Rural Development 18: 135-139.

Funderburg E. 2020. The role of organic matter in soil. Stock farm 10: 31-33.

Gomez KA and AA Gomez. 1995. Prosedur Statistik untuk Penelitian Pertanian. Universitas Indonesia Press. Jakarta. 698 p. (in Indonesian).

Hou L, X Zhang, G Feng, Z Li, Y Zhang and N Cao. 2021. Arbuscular mycorrhizal enhancement of phosphorus uptake and yields of maize under high planting density in the black soil region of China. Scientific Reports 11: 1-11.

Husson O. 2013. Redox potential (Eh) and pH as drivers of soil/plant/microorganism systems: a transdisciplinary overview points to integrative agronomy opportunities. Plant Soil 362: 389-417.

Karnilawati, Sufardi and Syakur. 2013. Phosfat tersedia, serapannya serta pertumbuhan jagung (Zea mays L) akibat amelioran dan mikoriza pada andisol. $J$ Manajemen Sumberdaya Lahan 2: 231-239.

Kumar S, RS Meena, D Jinger, HS Jatav and T Banjara. 2017. Use of pressmud compost for improving crop productivity and soil health. Int J Chem Stud 5:384-389. 
Mahendradatta M and AA Tawali. 2008. Jagung dan Diversifikasi Produk Olahannya. Masagena Press. Makassar. 90p. (in Indonesian).

Mulyani A, D Nursyamsi and M Syakir. 2017. Strategi pemanfaatan sumberdaya lahan untuk pencapaian swasembada beras berkelanjutan. Makalah Review. J Sumberdaya Lahan 11: 11- 22.

Muslim RQ, P Kricella, S Purwanto and S Ritung. 2020. Characteristics of inceptisols derived from basaltic andesite from several locations in volcanic landform. Sains Tanah 17: 115-120.

Ningrum DP, AMuhibuddin and T Sumarni. 2013. Aplikasi cendawan mikoriza arbuskular (CMA) dan bokashi dalam meminimalisir pemberian pupuk anorganik pada produksi benih tanaman jagung ketan (Zea mays Ceratina) J. Produksi Tanaman 1:398-407. (in Indonesian).

Nurbaity A, GC Uratel and JS Hamdani. 2019. Mycorrhiza enhanced protein and lipid contents of potatoes grown on inceptisol with addition of organic matter. J Trop Soils 24: 129-133.

Patra A, VK Sharma, T Purakayastha, M Barman, S Kumar, KA Chobe, D Chakraborty, DJ Nath and AS Anil. 2020. Effect of long-term integrated nutrient management (INM) practices on soil nutrient availability and enzymatic activity under acidic inceptisol of North Eastern Region of India. Comm Soil Sci Plant Anal 51: 1137-1149.

Pinos NQ, RL Louro Berbara, SS Elias, TA Van Tol de Castro and AC García. 2019. Combination of humic substances and arbuscular mycorrhizal fungi affecting corn plant growth. J Environ Qual 48: 1594-1604.

Pinto LC, CR de Mello, PR Owens, LD NorMg and N Curi. 2016. Role of inceptisols in the hydrology of mountainous catchments in Southeastern Brazil. $J$ Hydrol Eng 21: 05015017.
Püschel D, M Bitterlich, J Rydlová and J Jansa. 2020. Facilitation of plant water uptake by an arbuscular mycorrhizal fungus: a Gordian knot of roots and hyphae. Mycorrhiza 30: 299-313.

Rajapakse S and JC Jr Miller. 1992. Methods for studying vesicular-arbuscular mycorrhizal root colonization and related root physical properties. In: JR Norris, DJ Read and AK Varma (Eds). Methods in Microbiology 24. Academic Press, London, pp. 301-316.

Sinha SK, V Kumar and CK Jha. 2017. Effect of integrated use of bio-compost and nitrogen on productivity and soil properties of sugarcane plant-ratoon system in calcareous soil. Sugar Tech 19: 485-491.

Soepardi G. 1983. Sifat dan Ciri Tanah. Jurusan Tanah, Fakultas Pertanian IPB. Bogor. 591p. (in Indonesian).

Stevenson FJ. 1994. Humus Chemistry. GenesisComposition-Reaction. John Wiley and Sons. New York. $512 \mathrm{p}$.

Sutanto. 2002. Penerapan Pertanian Organik. Pemasyarakatan dan Pengembangannya. Kanisius. Yogyakarta. 232 p. (in Indonesian).

Wright SF and AUpadhyaya. 1998. A survey of soils for aggregate stability and glomalin, a glycoprotein produced by hyphae of arbuscular mycorrhizal fungi. Plant Soil 198: 97-107.

Yusra. 2010. Beberapa sifat kimia tanah, serapan P dan hasil jagung akibat pemberian kompos sampah pasar dan pupuk fosfat pada Fluventic Eutrudepts. [Disertasi]. Universitas Padjadjaran. Bandung (In Indonesian).

Zhang F, YN Zou and QS Wu. 2018. Quantitative estimation of water uptake by mycorrhizal extraradical hyphae in citrus under drought stress. Sci Hortic-Amsterdam 229: 132-136. 